\title{
The Subjective Well-Being of Portuguese Children in Foster Care, Residential Care and Children Living with their Families: Challenges and Implications for a Child Care System Still Focused on Institutionalization
}

\author{
Paulo Delgado \& João M. S. Carvalho \& Carme Montserrat \& \\ Joan Llosada-Gistau
}

\begin{abstract}
Most studies with children in out-of-home care highlight the problems and challenges associated with residential or foster care, and few have investigated the well-being of these children. The aim of this study is to compare the subjective well-being (SWB) of children hosted in institutions and in foster families with the well-being of children living with their families. We used a sample of 422 children, aged between 11 and 15 , being 39 in foster care, 145 in residential care, and 238 living with their families in the general population. We measured SWB with the Personal Well-being Index-School Children (PWI-SC9) and we evaluated the impact of several variables in this index. Results indicate that children in residential care have a lower SWB in all variables compared to foster care and general populations groups. These outcomes should challenge children's public policies to change from a dominant positive attitude toward institutionalisation to a more successful approach based on foster care families. This approach will provide the opportunity for children in out-of-home care to grow up in a family, and improve their SWB, which can probably ensure a better life trajectory.
\end{abstract}

Keywords: Children ${ }^{`}$ Subjective well-being ${ }^{\circ}$ Families ${ }^{\bullet}$ Foster care ${ }^{`}$ Residential care

\section{The Children's Subjective Well-Being}

It is possible to distinguish between three approaches to well-being (Parfit 1984). The first is based on objective lists of things that others think we need to achieve a good life. 
The second is based on preference satisfaction with things that we want to have in life. The third is based on mental states such as direct assessments of thoughts and feelings. There are a wide range of effects on individuals related to their feeling of SWB. For example, SWB affects human physiology (Pressman and Cohen 2005; Salovey et al. 2000); behavioural responses like approach and avoidance of something (Diener et al. 1999); or the level of mental health (Valois et al. 2004). Thus, analysing the variables that could affect children's SWB is important in order to achieve better decisions for their course of life.

Consequently, quality of life depends on objective material conditions and psycho-social aspects. The concept of subjective well-being is included in the second dimen-sion and can be defined as the perceptions, pretensions and assessments that people make of different factors and circumstances of their life (Casas 2011). The well-being included a Hedonic dimension, or subjective wellbeing, associated with happiness or life satisfaction, which is subdivided into the affective and cognitive components; and a Eudaimonic dimension, which refers to the self-acceptance, autonomy or propose in life (Casas 2011; Rees et al. 2013).

Although happiness is generally accepted as an indicator of subjective well-being (Ben-Arieh et al. 2014), it is a concept difficult to define and measure. Bruckner (2000) explained the volatility of this feeling, which may eventually be fully grasped only after it has already been lived. Nevertheless, happiness is associated with perspectives and needs of the individuals, their achievements, positive interpersonal interactions, opportunities and freedom to choose (Ben-Arieh et al. 2014). That's why the self-reported well-being express an opinion: a personal, intrinsic and relative representation of how someone feel adapt to the environment and the requests of life, in a particular moment.

Some of the factors influencing subjective well-being are personality factors, attain-ment of goals, comparisons with standards, the passage of time and the type of culture, more individualist or collectivist (Casas 2011; Casas and Bello 2012). Subjective social indicators, like health or school life, along with objective indicators, may be as useful in decision making and in social policies analysis, including those that are directed to childhood (Casas 2011). Ben-Arieh (2008) and Ben-Arieh et al. (2014) point out the growing effort to include children subjective perceptions in the research agenda, to develop multiple methods of analysis of negative and positive factors or behaviours in subjective well-being studies.

According to Bradshaw (2015), there are some important arguments to establish a relationship between subjective well-being and social policy, because policy can namely influence, directly or indirectly, the learning context (Alcantara et al. 2016), the relationships that children have with family (Dinisman et al. 2017; Llosada-Gistau et al. 2017) and friends (Llosada-Gistau et al. 2017; Casas 2011), the leisure time (The Children society 2013) or environment conditions (Children's Worlds 2016). Ben-Arieh et al. (2014) explore the relationship between SWB and rights. In their perspec-tive, the human rights treaties implicitly understand rights as a way to create well-being or opportunities for well-being in multiples areas, like material, social, cultural environments, as well as to their psychological or emotional development. They also concluded that an improvement of the "quality of public services has a positive impact on people's quality of life, including subjective well-being" (p.19).

Research on children's subjective well-being is recent. As Casas (2011) addressed, the perception of children and adolescents about their quality of life is essential, and it 
shouldn't be misunderstood with adult opinions of child well-being. This area of study assumes the idea that childhood is a specific stage of life that should provide the children's participation in the decisions that concern their life, according to their age and experience, and recognizing the importance of their opinion (González et al. 2015). In other words, it is based on the principle enshrined in the Convention on the Rights of the Child that children and adolescents have their own perspective about what is right or wrong for them, agreeing or disagreeing with adults. Those opinions provide a learning opportunity to adults as well as the chance to deep the intergenerational relationship (Ben-Arieh 2008).

The study Children's Worlds International Survey of Children's Well-Being (ISCWeB), whose third wave ends in 2019, involves countries from all continents around the world and collects data on children's lives and daily activities, their use of time and in particular to their own perceptions and evaluations of their well-being. The aim of this longitudinal study is to improve the well-being of children by disseminating knowledge about their daily lives on their own, with their families and within the community, and by promoting an understanding of their convictions and degree of satisfaction with the environment and relationships (Children's Worlds 2016).

\section{The Subjective Well-Being of Children in Care}

Although literature in this issue is still scarce, there has been recently some studies focusing on the subjective well-being of children in care. Most of the work focuses on subjective well-being of children in residential care compared to that of the general population and they all share a common result: the well-being of institutionalized children is significantly lower than that of children living with their families, regardless the age of the children or adolescents involved.

In France, Sastre and Ferrière (2000) concluded that well-being of adolescents living in children's homes appeared to be strongly affected, as also their life satisfaction and the feeling of personal growth. In Brasil, Dell'Aglio e Siqueiro (2010) identified as predictors of life satisfaction stressful events, social support network and family conflicts. These authors presented data on young people living in institutions and living with their disadvantaged families. Those two groups shared risk factors such as poor academic performance, stressful events and single-parent families, but it was found that the situation is more serious for institutionalized children and adolescents that presented a higher rate of school failure, higher number of siblings in average and a minor percentage of parents living together.

More recently, in the same country, Schütz et al. (2015) compared the subjective well-being of children in residential care centers versus those from the general popu-lation living with their families. The authors assumed as independent variables the Personal Well-Being Index - School Children (PWI-SC7) with seven items, the eight GDSI's domains and the Overall Life Satisfaction (OLS) single item scale, and as a dependent variable the group in which the children belong (foster care / families). The results indicate that all items are significantly better for children living with their families. On the other hand, children with less changes are able to maintain their social ties, which allow them to conclude that promoting well-being should be linked to greater placement stability. 
Llosada-Gistau et al. (2014) used the questionnaire of the International Survey of Children's Well-Being with two psychometric scales: the PWI-SC7 and the OLS to concluded that compared with the general population in Spain, adolescents in care score significantly lower in satisfaction means on both scales in relation to all studied items. They also found that adolescents living in residential care have fewer opportunities to decide on the use they make of their time, especially with regard to family relationships or free-time activities, and that boys present greater average score on OLS scale than girls in residential care. The study stresses the importance of children being consulted, giving them the opportunity to present their views on aspects of their lives. This should be taken into account both in terms of professional practice and research in this area.

Finally, in Peru, Ortúzar et al. (2019) analysed how self-control is related with subjective well-being, highlighting daily-life activities shared between and adolescents in the residential care system. The results show a positive and significant relationship between self-control and the cognitive and affective measurements of SWB, specifi-cally with Students Life Satisfaction Scale (SLSS).

Other advance in this field was the research conducted by Dinisman et al. (2012), which explores differences in SWB between young adolescents 'living in care', 'living in single parent families' and 'living in two-parent families'. They found that adoles-cents living in care have the least stable lives, followed by adolescents living with one parent, while adolescents living with two parents lead much more stable lives. How-ever, the study does not distinguish the type of care, that is, if the children stays in residential or foster care, which limits the results projection. Another study points out a negative effect of critical changes, like changing house or school, as often happens in child care, on adolescents' subjective well-being in seven of the eight countries analysed (Montserrat et al. 2015). These researchers concluded that fewer number of changes in the past year are associated with greater well-being, which highlights the importance of stability.

In Denmark, Heastbaek (2016) developed a study on 11 to 17-year-olds living in outof-home care and concluded that young people placed in residential care often display more serious problems than those referred to foster care. She also found out that they do not feel safe, heard, or loved by the adults around them to the same extent as do other young people in care; and only a third consider their residential home a very good place to grow up. In the same country, Lausten and Fredriksen (2016) analysed the subjective feeling of love amongst children living in out-of-home care and found that children in foster care more often reported that they feel loved by their caregiver, feel high social support, and to a large extent feel more secure with their caregivers than children in residential care or in socio-pedagogical homes.

The first study to compare the subjective well-being of children in residential care, foster care (kinship and non-kinship) and the general population was developed in Catalonia by Llosada-Gistau et al. (2017). The data collected show that the adolescents living in kinship and non-kinship foster care reported better SWB in all life domains than those in residential care. The variables that might have an influence in their subjective well-being are gender, age, the agreement with their placement, satisfaction with the school, their relationships with friends, and their use of time and access to a computer. In particular, children with higher SWB scores have a positive relationship with school, with teachers and classmates, and academic success, no matter the type of placement where they are living. 
Our study adapted to the Portuguese context the research developed by Joan Llosada and colleagues in Catalonia. The overall aim is to explore and compare the SWB of children living in residential and foster care with children integrated in the general population.

\section{Child Care in Portugal}

For some decades now, Western countries have been developing deinstitutionalization processes, privileging family alternatives such as foster care or adoption (Eurochild 2010; Del Valle and Bravo 2013). When reunification with the family of origin is not possible, the alternative for children, especially the younger ones, must be placement in another family that meets their basic needs for safety, affection and stimulation.

The priority given in the Convention on the Rights of the Child to placement in a family context, the low level of social development achieved by children and young people in institutions, the existence of scandals involving child and youth abuse in institutions, and attachment theory (Bowlby 1944, 1951; Rutter 1991, 1995) have sustained a growing commitment to family-based responses. This evolutionary trend is based on a child-centered approach that aims to enable all children, including those who are in out-of-home care, to fully exercise their rights, namely the right to grow up in a family context (Gilbert et al. 2011).

Foster care response, already consolidated for decades in central and northern European countries, still shows implementation rates that point towards a slow and difficult progression in the Portuguese case. The causes of Portuguese resistance to deinstitutionalization bring together different origins and dimensions. Throughout the twentieth century, large institutions of child and youth care were created, many of them from the Catholic Church, with the mission of supporting unprotected children or young people with behavioural disorders, thus replacing families and the community (Martins 2006).

Currently, the network of residential centers covers the entire national territory and provides more than enough places for all children and young people at risk. This reality makes it difficult to change, since these institutions seek to preserve their continuity, resisting to needed policy changes.

All these factors are combined with a social policy who clearly disregarded, in the last decade, foster care in relation to residential care. It was postponed the campaigns of recruitment and selection of foster families, the availability of the necessary resources to support the costs of foster care programmes, and the implementation of a tax policy that favours and reinforces this activity, compromising its development. This postpone-ment has been associated with a certain ambiguity in defining the future role of the framework entities, i.e., non-profit social organizations, vis-à-vis the State, more specifically the role currently played by the Social Security Institute (Delgado 2015).

Foster care was legally recognized in 1979. As a consequence of the establishment of a new system of foster care implementation (Decree-Law 11/2008), a restricted scope of action was put in place, allowing only families without blood ties to do foster care, which significantly reduced the role played by this social response within the childcare system. In 2007, the last year for which official data is available, there were 979 children and young people in Kinship Care. 
In Portugal, in 2016, there were 8175 children in out-of-home care, of which only $3.1 \%$ were in foster families. Besides, it should be noted that only 18 of 1072 children under 6 years old in care were living with foster families, accounting only for $1.7 \%$ of the total (Instituto da Segurança Social 2017). In the last 10 years, from 2007 to 2016, and despite a reduction of near $17 \%$ in the total number of children in residential care, institutionalisation has risen in relative terms when compared to foster care.

The care system presents a slight prevalence of male children and young people 4307 (52.7\%) boys, compared to 3868 (47.3\%) girls. Regarding the age groups, it is clear the prevalence of adolescents in the age group 15-17 years, with a weight of $35.6 \%$ (2914). Next, we find the groups with $12-14$ years $(19.4 \%$ - 1588) and $18-$ 20 years $(14.4 \%-1174)$. That is, $69.4 \%$ of children and young people are over 12 years of age. If we look at the age distribution by type of placement, we find that the age group over 12 years old represents $78 \%$ in foster care and $70 \%$ in residential care. There were not young offenders included in this group.

Regarding the type of predominant abuse, the various forms of negligence stand out, accounting for $72 \%$, followed by situations of psychological maltreatment $(8.5 \%)$. Physical abuse is also significant (3.4\% of children), as well as sexual abuse $(2.8 \%)$. As regards mental health problems and intellectual or physical disabilities with clinical diagnosis, 35\% (92) of children and young people were in foster care and $1711(22 \%)$ were in residential care (Instituto da Segurança Social 2017).

Out-of-home placement is characterised by permanence. The child or young person tends to stay in care for a long time, sometimes until they are 18 or become indepen-dent. In fact, $35 \%$ of children and young people have been in care longer than 4 years. In the case of foster care, this figure rises to $74 \%$. If we add those who have been fostered longer than 2 years, we can conclude that $56 \%$ of the children and young people in out-of-home care and $84.3 \%$ of the children and young people in foster care are in a long-term placement (Instituto da Segurança Social 2017).

At the research level, recent studies have shown the positive result obtained by children and young people in foster care (Delgado 2013) and the reduced and limited outcomes of children and young people in residential care (Martins et al. 2013; Oliveira et al. 2014). However, considering the figures above, it appears to be evident that the change produced in most Western countries, namely the disappearance of large residential care institutions and the commitment to foster care, is yet to take place in Portugal.

In 2011, the residential child care network in continental Portugal included 207 Lares de Infância e Juventude (long-term care), where about $73 \%$ of children in residential care lived, and 127 Centros de Acolhimento Temporário (short term care), where the remaining 27\% lived (Rodrigues et al. 2013). In the larger Lares de Infância e Juventude, the application of family-style model (Bravo and Del Valle 2009) comes up against structural problems, such as those related to the architecture and size of the buildings, resistance to changes in their organization and functioning, segregation by sex and by age/developmental level, an increasing age of the population and the inclusion of staff without specific training. In Portugal, the move to specialization is still just beginning, with only a few recent initiatives involving emergency units or apartments for independent living, which may help the adolescents and pre-adults to prepare their transition to independence (Rodrigues et al. 2013). More than $60 \%$ of the residential units continue to be large houses, with more than 25 children or young people (Rodrigues and Barbosa-Ducharne 2017). 
The amendment of the Law on Protection of Children and Yong People in Danger, carried out by Law 142/2015 of September 8th, introduced significant changes in the system protection of children and young people in danger. The aim of the intervention or the choice between foster and residential care, are good examples of those changes, since they are designed to favour foster care, the maintenance of the relationship with the foster carers, and the permanence in that context, independently or in parallel to the relationship with the biological family. More, since 2015, it is possible to adopt directly from foster care, and foster care is preferred to residential care, especially for children up to 6 years old. Nevertheless, these changes need to be regulated in order to become concrete measures and be implemented in practice.

\section{Objectives}

All these studies and figures highlight the importance and urgency of questioning the dominant institutionalization pattern in Portugal, and conducting research on residential care quality, to assess the extent to which this social response meets the real needs of the children, as Rodrigues et al. proposed (Rodrigues et al. 2013). There is still a lack of studies on the SWB of children in residential care in countries like Portugal where this type of placement is the most widespread. To cover this gap, we adapted to the Portuguese context the research developed by Llosada and colleagues (Llosada-Gistau et al. 2014, 2017), being its aims to explore and compare the SWB of children living in residential and foster care with their peers from general population.

More specifically, the study objectives are focused on knowing the subjective wellbeing according to: (a) the relations that they have in their placement and family; (b) the relationships that the children have at school; (c) the perception about themselves; and d) the factors that most contribute for its change. The fact of focusing on these variables is due to the importance of the sphere of interpersonal relations in subjective well-being studies and especially in the environment closest to children, such as their nucleus of coexistence and school (Children's worlds 2016).

\section{Methods}

\subsection{Samples}

We carried out a cross-sectional study in Portugal in 2018. The study population comprised children in general population and in care aged between 11 and 15. On one hand, a sample of 238 children on general population attending schools from large, medium and small cities, from the interior and coast of the country, from north to south, and despite it is not a randomize sample, it represents different parts and realities in Portugal. Children were between 11 and 15 years old $(\mathrm{M}=12.42 ; \mathrm{SD}=1.13)$ like in the other samples of children in care. They were $49.6 \%$ male and $50.4 \%$ female.

On the other hand, there is the sample of children in residential care that included 145 respondents with an average age of $13.51(\mathrm{SD}=1.26)$, being $41.4 \%$ male and $58.6 \%$ female. There were 6 children that were not Portuguese (Angola, Brazil, Spain, Guinea-Bissau, Poland, and Tanzania). In terms of ethnicity, 111 were White, 23 
Mulattos, 6 Black, and 5 Gipsy children. This sample was obtained by randomly choosing residential homes among four Portuguese districts.

Finally, the sample of children in foster care included all the children (44) hosted in the same four districts. Five of these children with great disabilities were unable to answer to the questionnaire. Thus, it remained 39 children in this sample with an average age of $13.27(\mathrm{SD}=1.42$ ), being $46.2 \%$ male and $53.8 \%$ female.

The samples of children in care are representative because they were chosen in four districts with more concentration of the two types of care, only in the group with age between 11 and 15-years-old, being all the children in foster care, and $24 \%$ of children in residential care.

\subsection{Questionnaire}

The data were obtained by administering the International Survey of Children's Well-being questionnaire (ISCWeB; www.isciweb.org), which had been adapted and pre-tested in both realities of the Portuguese children. All interviewers were trained on the content of this questionnaire and its mode of administration, allowing to reduce possible biases in its application.

The questionnaire has responses to 44 questions grouped into 11 thematic sections: personal information (6 questions), the relationship with your parents (8), home and the people you live with (8), the things you have (2), friends and other people (3), the area where you live (2), school (3), how you use your time (1), more about you (2), how you feel about yourself (4), and your life and your future (5).

\subsection{Variable Measures}

The questionnaire was self-administered and included the version of the Personal Well-being Index-School Children (PWI-SC) that was developed by Cummins et al. (2003). It was originally created to measure subjective well-being in adults and was later adapted by Cummins and Lau (2005) for children, consisting of seven items. In our study, we used nine items, the last two being added by Casas et al. (2012), which relate to the use of time and life as a student. The scale ranges from 0 (not at all satisfied) to 10 points (totally satisfied). In this study, the reliability of PWI-SC9 was very good $(\alpha=0.85)$.

The general question in this scale is "How satisfied are you with each of the following things in your life": (1) The things you have; (2) Your health; (3) The secure you feel; (4) The things you know you do well; (5) Your relationships in general; (6) The things you do outside your home (host house); (7) What could happen later in your life; (8) Your use of time; and (9) Your life as a student. We used the scores' mean in this scale to represent it.

The independent variables included in the study were those related to personal characteristics - gender (male and female) and age (11 to 13, and 14 to 15) -, and those related to the 3 specific objectives of the study:

a) Regarding the placement or family where they live and satisfaction with family or carers (scale 0-10) and children's type of placement (general population, foster care and residential care). 
b) Regarding education: children's perceptions and evaluations of relationships at school and leisure activities. It is: satisfaction with friends (scale 0-10), liking going to school (I don't agree, I agree a little, I agree in part, I strongly agree, and I totally agree), frequency of being victim of bullying in the last month (Never, Once a month, Twice or three times, More than three times), frequency of being left out by other children of their class in the last month (Never, Once a month, Twice or three times, More than three times), relationship with teachers (scale 0-10), frequency of extracurricular activities - music, dance, sports, languages, etc. - (Never or rarely, Less than once per week, Once or twice a week, Almost or every day).

c) About themselves: feeling lonely (Scale 0-10), satisfaction with the way that you look (Scale 0-10), feeling positive about my future (Scale 0-10)

\subsection{Data Analysis}

In all the analyses presented here, the PWI-SC9 is considered the dependent variable and the rest independent. The mean and standard error of the PWI-SC9 scale were calculated for each independent variable according to Type of placement. The Student's t test, ANOVA, bivariate correlation and linear regression were used. We have per-formed a linear regression with all independent variables for each group of children; and other one with all variables for all the children. All the data analysis was performed with IBM.SPSS.23.

\subsection{Ethical Issues}

Throughout the data collection process, the researchers provided an explanation of the study, ensuring the confidentiality and anonymity of the responses, as well as the nonobligation to respond to the survey or, responding, the possibility of not responding to any question when they felt unprepared or uncomfortable. The researchers obtained the consent of all institutions (Portuguese Social Security, residential homes, schools and foster families) and all the children to respond to the survey.

\section{Results}

The results are explained according to the objectives of the study. Regarding the placement, we can see on Table 1 that the group of children in residential care displays lower level of subjective well-being (SWB) comparing to the other two groups with statistical significance. Between the groups of children in foster care and in the general population, there is no significant differences in their assessment of SWB. In addition, significant differences were observed by sex: girls in residential care show a lower SWB in relation to the girls of the other two groups, as well as in relation to boys in the same population. SWB decreases also with age in residential care and in general population, but without statistical significance.

Concerning education, there are statistical significant differences between SWB of children in residential care in relation to children in general population in all categories of answer to the item 'liking going to school'. Children who like more going to school 
Table 1 PWI-SC9 values discriminated by groups according to variables related to the objectives

\begin{tabular}{|c|c|c|c|c|c|c|}
\hline \multirow[b]{3}{*}{ Gender } & \multicolumn{6}{|c|}{ PWI-SC9 } \\
\hline & \multicolumn{2}{|c|}{ General population } & \multicolumn{2}{|c|}{ Foster family care } & \multicolumn{2}{|c|}{ Residential care } \\
\hline & $\mathrm{n}$ & Mean (SD) & $\mathrm{n}$ & Mean (SD) & $\mathrm{n}$ & Mean (SD) \\
\hline Female & 120 & $9.11(1.29)$ & 18 & $8.71(1.05)$ & 85 & $* * * 7.55(1.87)$ \\
\hline Male & 116 & $9.12(0.91)$ & 21 & $8.80(1.04)$ & 60 & $* * * 8.25(1.55) *$ \\
\hline \multicolumn{7}{|l|}{ Age } \\
\hline 11 to 13 & 197 & $9.15(1.08)$ & 21 & $8.70(1.24)$ & 64 & $* * * 8.04(1.58)$ \\
\hline 14 to 15 & 39 & $8.96(1.28)$ & 18 & $8.82(0.74)$ & 81 & $* * * 7.68(1.91)$ \\
\hline \multicolumn{7}{|l|}{ Placement } \\
\hline Type of placement & 236 & $9.12(1.12)$ & 39 & $8.76(1.03)$ & 145 & *** 7.84 (1.77) \\
\hline \multicolumn{7}{|l|}{ Education } \\
\hline \multicolumn{7}{|l|}{ Liking going to school } \\
\hline I don't agree & 28 & $8.83(1.49)$ & 4 & $8.56(0.33)$ & 29 & $* * 7.26(2.07)$ \\
\hline I agree a little or in part & 79 & $8.86(0.99)$ & 17 & $8.59(1.06)$ & 41 & $* * * 7.34(1.79)$ \\
\hline I strongly or totally agree & 127 & $9.41(0.66)^{* *}$ & 18 & $8.96(1.11)$ & 75 & $* * * 8.34(1.49) *$ \\
\hline \multicolumn{7}{|c|}{ How often other kids beat you up in the last month } \\
\hline Never & 214 & $9.16(0.95)$ & 35 & $8.84(0,93)$ & 120 & $* * * 7.84(1.83)$ \\
\hline Once to three times & 16 & $9.13(0.82)$ & 2 & $8.83(0.71)$ & 15 & $* 7.88(1.52)$ \\
\hline More than three times & 2 & $8.06(1.81)$ & 1 & $8.78(0.00)$ & 8 & $7.89(1.59)$ \\
\hline \multicolumn{7}{|c|}{ Frequency of being left out by other children of their class in the last month } \\
\hline Never & 182 & 9.35 & 28 & $8.99(0.98)$ & 98 & $* * * 7.99(1.79)$ \\
\hline Once to three times & 31 & 8.32 & 6 & $7.70(1.12)$ & 27 & $7.64(1.58)$ \\
\hline More than three times & 10 & $8.18 *$ & 5 & $8.71(0.10)$ & 16 & $7.62(1.78)$ \\
\hline \multicolumn{7}{|c|}{ How often do you do extracurricular activities } \\
\hline Never or rarely & 65 & $9.12(0.86)$ & 21 & $8.56(1.22)$ & 67 & *** 7.47 (1.95) \\
\hline Once or twice a week & 77 & $9.03(1.17)$ & 7 & $8.89(0.82)$ & 39 & *** $7.79(1.60)$ \\
\hline Almost or every day & 88 & $9.31(0.77)$ & 11 & $9.04(0.69)$ & 35 & $* 8.50(1.45) *$ \\
\hline
\end{tabular}

On the left: in relation to general population group; on the right: within the same group $* \mathrm{p}<.05 ; * * \mathrm{p}<.01 ; * * * \mathrm{p}<.001$

presents higher SWB in the groups of residential care and in general population. It is clear that children in residential care shows less SWB in the other variables of education, most of them with statistical significance.

In Table 2, we can see that all those variables are positive correlated with PWISC9, with statistical significance. Again, it is the residential care group that has a lower level in each variable: namely the satisfaction with the relationships with caregivers (place-ment), and with teachers and friends in the school. About themselves the variables related to how they look, the feeling of loneliness and the feeling less positive about their future.

In the linear regressions (Table 3), we can see in the first model for each group of children that we have $\mathrm{R}^{2}=.687$ as the explained variance of the model in 


\begin{tabular}{|c|c|c|c|c|c|c|}
\hline & \multicolumn{2}{|c|}{ General population } & \multicolumn{2}{|c|}{ Foster family care } & \multicolumn{2}{|c|}{ Residential care } \\
\hline & $\mathrm{n}$ & $\begin{array}{l}\text { Mean (SD) } \\
\text { Correlation } \\
\text { with PWI-SC9 }\end{array}$ & $\mathrm{n}$ & $\begin{array}{l}\text { Mean (SD) } \\
\text { Correlation } \\
\text { with PWI-SC9 }\end{array}$ & $\mathrm{n}$ & $\begin{array}{l}\text { Mean (SD) } \\
\text { Correlation } \\
\text { with PWI-SC9 }\end{array}$ \\
\hline \multicolumn{7}{|l|}{ Placement } \\
\hline $\begin{array}{l}\text { Satisfaction with family (carers) } \\
\text { and other persons you live with at home }\end{array}$ & 233 & $\begin{array}{l}9.49(0.99) \\
.408 * * *\end{array}$ & 39 & $\begin{array}{l}9.12(1.47) \\
.660 * * *\end{array}$ & 143 & $\begin{array}{l}7.66(2.11) * * * \\
.693 * * *\end{array}$ \\
\hline \multicolumn{7}{|l|}{ Education } \\
\hline $\begin{array}{l}\text { How satisfied are you with your } \\
\text { relationship with teachers }\end{array}$ & 235 & $\begin{array}{l}8.47(1.82) \\
.491 * * *\end{array}$ & 38 & $\begin{array}{l}9.11(1.41) \\
.655 * * *\end{array}$ & 143 & $\begin{array}{l}7.69(2.72) * * * \\
.586 * * *\end{array}$ \\
\hline How satisfied are you with your friends & 234 & $\begin{array}{l}9.32(1.36) \\
.636 * * *\end{array}$ & 39 & $\begin{array}{l}8.79(2.11) \\
.599 * * *\end{array}$ & 145 & $\begin{array}{l}8.21(2.47) * * * \\
.424 * * *\end{array}$ \\
\hline \multicolumn{7}{|l|}{ Yourself } \\
\hline I feel lonely & 233 & $\begin{array}{l}2.14(3.38) \\
-.126^{*}\end{array}$ & 39 & $\begin{array}{l}2.77(3.71) \\
-.364 *\end{array}$ & 145 & $\begin{array}{l}3.30(3.70) * * \\
-.110\end{array}$ \\
\hline Satisfaction with the way I look & 231 & $\begin{array}{l}8.89(2.01) \\
.619 * * *\end{array}$ & 38 & $\begin{array}{l}8.47(2.47) \\
.393 *\end{array}$ & 143 & $\begin{array}{l}8.01(2.59) * * \\
.520 * * *\end{array}$ \\
\hline I feel positive about my future & 234 & $\begin{array}{l}8.44(2.15) \\
.485 * * *\end{array}$ & 39 & $\begin{array}{l}7.82(2.28) \\
.327 *\end{array}$ & 144 & $\begin{array}{l}7.13(3.04) * * * \\
.429 * * *\end{array}$ \\
\hline
\end{tabular}

$* \mathrm{p}<.05 ; * * \mathrm{p}<.01 ; * * * \mathrm{p}<.001$

residential care; $\mathrm{R}^{2}=.794$ in the model for foster care; and $\mathrm{R}^{2}=.642$ for the model in general population, which are very good when we have used only some of the variables. The collinearity statistics - Tolerance and Variance inflation factor - are both near of ' 1 ', thus there is no excess of collinearity in these models.

It seems that for all children - living with their families, with foster carers and in residential homes - the relationships with their family or caregivers and with teachers and to feel positive about the future are three important factors associated to better SWB. For children both in residential and for their peers of general population, it seems also relevant how they look. Finally, the relationships with friends are more highlighted by children in the general population.

Eliminating from the model the variables that don't have statistical significance, we come to the final model that explains $70.4 \%$ of total variance (Table 4).

In this linear regression we include dummy variables to measure the impact of being from different groups. It is shown that children in care have less subjective well-being than children in general population, being the differences higher in the group of residential care with statistical significance at the level of $10 \%$. The ranking of impact on SWB is leaded by the satisfaction with the relationship with their family or carers $(\beta=.399)$, followed by the satisfaction of their relationship with teachers $(\beta=.232)$, the satisfaction with the way they look $(\beta=.213)$, the positive feeling about their future $(\beta=.184)$, the satisfaction with their friends $(\beta=$ $.108)$, and the performance of extracurricular activities $(\beta=.074)$. 


\begin{tabular}{|c|c|c|c|c|c|c|c|c|c|}
\hline & \multicolumn{3}{|c|}{ General population } & \multicolumn{3}{|c|}{ Foster care } & \multicolumn{3}{|c|}{ Residential care } \\
\hline & $\mathrm{B}$ & $\begin{array}{l}\text { Std. } \\
\text { error }\end{array}$ & Beta & $\mathrm{B}$ & $\begin{array}{l}\text { Std. } \\
\text { error }\end{array}$ & Beta & $\mathrm{B}$ & $\begin{array}{l}\text { Std. } \\
\text { error }\end{array}$ & Beta \\
\hline Gender (ref.: girls) & -.124 & .076 & -.078 & .222 & .176 & .148 & .178 & .201 & .051 \\
\hline Age (ref.: 11-13) & -.075 & .107 & -.034 & -.452 & .175 & $-.302 *$ & -.121 & .184 & -.035 \\
\hline \multicolumn{10}{|l|}{ Placement } \\
\hline $\begin{array}{l}\text { Satisfaction with family } \\
\text { (carers) and other persons } \\
\text { you live with at home }\end{array}$ & .217 & .048 & $.228^{* * *}$ & .313 & .087 & $.437 * *$ & .321 & .056 & $.392 * * *$ \\
\hline \multicolumn{10}{|l|}{ Education } \\
\hline $\begin{array}{l}\text { Liking going to school } \\
\text { (ref.: I don't agree) }\end{array}$ & .050 & .059 & .043 & .015 & .126 & .014 & .074 & .139 & .033 \\
\hline $\begin{array}{l}\text { How often other kids beat } \\
\text { you up in the last month } \\
\text { (ref.: never) }\end{array}$ & -.110 & .111 & -.045 & .402 & .226 & .209 & -.023 & .177 & -.007 \\
\hline $\begin{array}{l}\text { Frequency of being left out by } \\
\text { other children of their class in } \\
\text { the last month (ref.: never) }\end{array}$ & -.176 & .080 & $-.111^{*}$ & -.138 & .121 & -.132 & -.098 & .162 & -.038 \\
\hline $\begin{array}{l}\text { How often do you do } \\
\text { extracurricular activities } \\
\text { (ref.: never or rarely) }\end{array}$ & .033 & .046 & .033 & .000 & .089 & .000 & .206 & .113 & .100 \\
\hline $\begin{array}{l}\text { How satisfied are you with your } \\
\text { relationship with teachers }\end{array}$ & .077 & .025 & $.157 * *$ & .401 & .092 & $.661^{* * *}$ & .174 & .044 & $.271^{* * *}$ \\
\hline $\begin{array}{l}\text { How satisfied are you with } \\
\text { your friends }\end{array}$ & .207 & .034 & $.323^{* * *}$ & -.067 & .059 & -.172 & .006 & .044 & .009 \\
\hline \multicolumn{10}{|l|}{ Yourself } \\
\hline I feel lonely & .005 & .011 & .021 & -.043 & .024 & -.213 & .009 & .028 & .019 \\
\hline Satisfaction with the way I look & .122 & .023 & $.256^{* * *}$ & .061 & .039 & .199 & .137 & .043 & $.209^{* *}$ \\
\hline I feel positive about my future & .076 & .018 & $.191^{* * *}$ & .085 & .038 & $.260 *$ & .115 & .033 & $.203 * *$ \\
\hline $\mathrm{R}_{2}$ & .687 & & & .794 & & & .642 & & \\
\hline
\end{tabular}

$* \mathrm{p}<.05 ; * * \mathrm{p}<.01 ; * * * \mathrm{p}<.001$

\section{Discussion}

With the results obtained in this study we can observe, for the first time in Portugal, the differences in terms of the subjective well-being of children living in a family environment - their family of origin or their host family - and Children living in a residential environment. The latter show a significantly lower subjective well-being, that is, they have less satisfaction with life. We could think that the determining factor may have been the situation of lack of protection that they had lived with the family of origin and had motivated their entry into the protection system, but then they probably would have obtained similar scores to those of children in foster care. On the other hand, despite the fact that the SWB of children in foster care is lower than that of their peers in the general population, this difference is not enough to achieve significance. That is, the welfare of the children in foster care is more similar to that of their peers in the general 


\begin{tabular}{lccc}
\hline & B & Std. error & Beta \\
\hline (Constant) & $1.780^{* * *} .289$ & \\
Residential care (ref.: general population) & -.164 & .098 & $-.056^{*}$ \\
Foster care (ref.: general population) & -.125 & .136 & -.026 \\
Satisfaction with family (carers) and other persons you live with at home & .329 & .032 & $.399^{* * *}$ \\
How often do you do extracurricular activities (ref.: never or rarely) & .125 & .047 & $.074^{* *}$ \\
How satisfied are you with your relationship with teachers & .154 & .021 & $.232^{* * *}$ \\
How satisfied are you with your friends & .079 & .024 & $.108^{* * *}$ \\
Satisfaction with the way I look & .134 & .019 & $.213^{* * *}$ \\
I feel positive about my future & .102 & .017 & $.184^{* * * *}$ \\
\hline
\end{tabular}

$* \mathrm{p}<.1 ; * * \mathrm{p}<.01 ; * * * \mathrm{p}<.001$

population, which could indicate that the residential environment is not sufficiently compensating for the situation of vulnerability that these children have compared with what can be obtained in a family environment. These results confirm what has begun to be seen in other studies (Llosada-Gistau et al. 2014, 2017; Schütz et al. 2015).

Other very important aspect is the issue of sex: girls in residential care have a significantly lower subjective well-being, compared with children in the same situation. But it is not observed either with the girls in foster care or with their peers in the general population. This result is in line with some recent studies that address the subject of SWB with populations in adverse situations such as poverty, bullying or with many changes in their life trajectories (Montserrat et al. 2015). That is to say, a gender issue is pointed out: girls in adverse situations show more affectation in their well-being, which can have important implications for professional practice. Also, it seems that the residential centre is not providing enough what the girls need. In parallel, one of the factors that all the participants of the three samples agree on is the importance for their well-being of satisfying relationships with their relatives, carers or educators. Having a good relationship with the people who care for them is crucial for their well-being and one of the reasons that explain these differences between those who live in residential care and those who live in a family: the stability of the adult figures and the type of link is usually more consistent in a family environment. In this sense, Dinisman et al. (2012, 2017) pointed out that often the family structure is not as important for well-being as the stability offered to the child, and therefore in this sense the frequent changes in the staff of residential centres do not help. A study by Melendro et al. (2016) highlighted the importance for adolescents at risk of the relationship with educators, a key factor of resilience (also in Ortúzar et al. 2019).

It is also observed that the well-being decreases with age and significantly in those who live in residential centres. However, this issue is the one that is more similar to the behaviour observed in studies with population at these ages, between 12 and 16 years, that show a downward line in levels of subjective well-being (Casas 2011).

Likewise, the importance of interpersonal relationships in the educational field stands out as a factor associated with well-being, such as satisfaction with the relation-ship with teachers and with classmates at school. The fact that the three groups agree on 
highly valued relationships with teachers and how this can affect their well-being in positive or negative way is a result with important implications for the practice, both with the general population and in work with vulnerable population. That is, the positive link with the teacher, as well as with their friends, can favour school inclusion, school learning and increase positive expectations about the future. However, to have satisfactory relationships with teachers and peers it is important not to change school frequently, and this is the situation in which those who are in the protection system are most often found. There are several studies that point out the importance of school in life for children in general (Jackson and Cameron 2014) and especially for those in residential centers. For the latter the school should be an opportunity and not a problem as it usually happens (Montserrat and Casas 2018).

Participation in leisure activities is also important, and in this study we can see that the children in residential care value it a lot. One explanation may be the sense of 'normality', of playing and of less exigency that children have for being able to participate regularly in extracurricular activities. This result also has implications for professional practice with recommendations to promote the inclusion of children in the protection system in normalized leisure activities, outside of the residential environment.

Moreover, in this study factors related to the most personal aspects have been observed: how they see themselves and how they perceive their future, two key factors also for their well-being (also observed with care leavers in Jackson and Cameron 2014). This is important for children of the general population, but its incidence on children in the protection system is more complex: how they see themselves leads us to think that they may have a less positive self-image, often the negative image that is transmitted to them from the outside world; and on the other hand the insecurity about what can happen to them in the future, which is uncertain for them and also for their educators. These two factors open up a range of possibilities for improvement when intervening with this population: the need to work to increase their self-esteem, selfconfidence and increase future expectations, as well as being able to know and actively participate in the construction of their future life trajectory.

This study has limitations related to the use of a long questionnaire applied by different people along the country. The fact that in Portugal foster care is a social response more and more less used led to a small population in the study. However, it is all population and not a sample.

\section{Conclusion}

Our findings allow us to highlight the need to changes in children's public policies from a dominant attitude toward institutionalisation to a more successful approach based on foster care. These results are especially relevant in protection systems of countries such as Portugal, Spain or Italy, where residential care has a significant expression. In the current Portuguese context, where only about $3 \%$ of the children are in foster care, it is essential to develop a process of deinstitutionalization. This implies giving the opportunity to a significant number of children and young people who are in big institutions to foster families. This does not mean that all children can or should make this change.

This study is particularly important in the current situation because in general it shows that the foster family is able to promote the well-being of the children in a more 
effective way than the residential homes, in line with other studies in the same area, such as Lausten and Fredriksen (2016). It is also important to pay attention to kinship care placements, a type of solution that has expression in several countries, namely in Spain (Del Valle et al. 2009), and have lost its legal role in the Portuguese protection system. This approach will provide the opportunity for children in out-of-home care to grow up in a family, and improve their SWB, which can probably ensure a better life trajectory. It is urgent to replace children's homes for foster families, and we could start with the group of more than 900 children, until 6 years of age, that are still living in institutions. Additionally, we would like to express the need to increase the number of research projects about out-of-home care, in order to develop more scientific knowledge about it, as well as to the development of effective evaluation processes of residential care centres to monitor their activity. The international comparison of out-ofhome care systems allows learning from diversity, commonalities and differences.

For further research it would be important to explore whether the size, the location and the type of children's institutions have influence on the scale responses. With regard to children in foster care, it would be interesting to analyse whether the length of stay in the actual placement or the existence in the foster family of other children with similar ages determines differences in SWB. We observe in Llosada-Gistau et al. (2017) that in Spain children living in big residential centres show a lower SWB comparing with those living in small residential homes and also the permanence in the same placement was a positive factor. In addition both for children in care and of general population, there is an increasing need to understand which social diversification processes, like ideologies, religious and/or ethnic backgrounds, economic inequalities, or migration processes, have an impact in children's SWB. Although in Portugal kinship care is not legally a modality of foster care, since 2008, the true is that a group of children continues to be delivered to the custody of their relatives, specially their grandparents. In future research, it will be useful to study the SWB of children in 'kinship care' and compare this with those from general population, residential care and foster care. Finally, the use of qualitative methods in future studies may be an important complement to this area of research, giving children the opportunity to express their opinion, for instance in interviews or in focus groups, about the factors that influence the well-being in the different domains of their lives.

\section{References}

Alcantara, S. C., González-Carrasco, M., Montserrat, C., Viñas, F., Casas, F., \& Abreu, D. P. (2016). Peer violence in the school environment and its relationship with subjective well-being and perceived social support among children and adolescents in Northeastern Brazil. Journal of Happiness Studies, 18, 1507- 1532. https://doi.org/10.1007/s10902-016-9786-1.

Ben-Arieh, A. (2008). The child indicators movement: past, present and future. Child Indicators Research, 1, 3-16. https://doi.org/10.1007/s12187-007-9003-1. 
Ben-Arieh, A., Casas, F., Frønes, I., \& Korbin, J. (2014). Multifaceted concept of child well-being. In A. Ben-Arieh, F. Casas, I. Frønes, \& J. Korbin (Eds.), Handbook of child well-being (pp. 1-28). New York: Springer. https://doi.org/10.1007/978-90-481-9063-8_134.

Bradshaw, J. (2015). Subjective well-being and Social policy: can nations make their children happier? Child Indicators Research, 8, 227-241. https://doi.org/10.1007/s12187-014-9283-1.

Bowlby, J. (1944). Forty-four juvenile thieves: their characters and home life. The International Journal of Psycho-Analysis, 25, 19-52.

Bowlby, J. (1951). Maternal care and mental health. New York: Schocken.

Bravo, A., \& Del Valle, J. F. (2009). Crisis y revisión del acogimiento residencial. Su papel en la protección infantil. Papeles del Psicólogo, 30(1), 42-52.

Bruckner, P. (2000). L’Euphorie Perpétuelle. Paris: Éditions Grasset et Fasquelle.

Casas, F. (2011). Subjective social indicators and child and adolescent well-being. Child Indicators Research, 4, 555-575.

Casas, F., \& Bello, A. (2012). Calidad de vida y bienestar infantil subjetivo en España. Madrid: UNICEF.

Casas, F., Sarriera, J., Alfaro, J., González, M., Malo, S., Bertran, I., et al. (2012). Testing the personal wellbeing index on 12-16 year-old adolescents in 3 different countries, with new items. Social Indicators Research. https://doi.org/10.1007/s11205-011-9781-1.

Children's Worlds. (2016). Children's views on their lives and well-being in 17 countries: key messages from each country. S.L.: Children's Worlds.

Cummins, R., Eckersley, R., Pallant, J., Van Vugt, J., \& Misajon, R. (2003). Developing a national index of subjective wellbeing: the Australian unity wellbeing index. Social Indicators Research, 64(2), 159-190.

Cummins, R., \& Lau, A. (2005). Personal wellbeing index-school children (PWI-SC) manual (3rd ed.). Victoria: School of Psychology Deakin University.

Dell'Aglio D. e Siqueiro, A. (2010). Preditores de Satisfação de Vida de Jovens em Situação de Vulnerabilidade no Sul do Brasil. Psicodebate, 10, 213-230.

Del Valle, J. F., López, M., Montserrat, C., \& Bravo, A. (2009). Twenty years of foster care in Spain: Profiles, patterns and outcomes. Children and Youth Services Review, 31, 847-853. https://doi.org/10.1016/j. childyouth.2009.03.007.

Del Valle, J., \& Bravo, A. (2013). Current trends, figures and challenges in out of home child care: an international comparative analysis. Psychosocial Intervention, 22, 251-257. https://doi.org/10.5093 /in2013a28.

Delgado, P. (Coord.) (2013). Acolhimento Familiar de Crianças. Evidências do presente, desafios para o futuro. Porto. Livpsic.

Delgado, P. (2015). Em busca do tempo perdido: o acolhimento familiar em Portugal. In O. Fernandes e C. Maia (Coord.) A Família Portuguesa no Século XXI (pp. 101-110). Lisboa: Parsifal.

Diener, E., Suh, E. M., Lucus, R. E., \& Smith, H. L. (1999). Subjective well-being: three decades of progress. Psychological Bulletin, 125, 276-302.

Dinisman, T., Montserrat, C., \& Casas, F. (2012). The subjective well-being of Spanish adolescents: variations according to different living arrangements. Children and Youth Services Review, 34, 2374-2380. https://doi.org/10.1016/j.childyouth.2012.09.005.

Dinisman, T., Andresen, S., Montserrat, C., Strózik, D., \& Strózik, T. (2017). Family structure and family relationship from the child well-being perspective: findings from comparative analysis. Children and Youth Services Review, 80, 105-115. https://doi.org/10.1016/j.childyouth.2017.06.064.

Eurochild. (2010). Children in alternative care - national surveys. Bruxelas: Eurochild.

Gilbert, N., Parton, N., \& Skivenes, M. (2011). Child Proctetion systems. New York: Oxford University Press.

González, M., Gras, M. E., Malo, S., Navarro, D., Casas, F., \& Aligué, M. (2015). Adolescents' perspective on their participation in the family context and its relationship with their subjective well-being. Child Indicators Research, 8, 93-109. https://doi.org/10.1007/s12187-014-9281-3.

Heastbaek, A.-D. (2016). The rights of children placed in out-of-home care. In A. Falch-Eriksen \& E. Backe-Hansen (Eds.), Human rights in child protection. Implications for professional practices and policy (pp. 129-146). Oslo: Palgrave MacMillan.

Instituto da Segurança Social, I.P. (2017). CASA - Relatório de caracterização anual da situação de acolhimento das crianças e jovens. Lisboa. Instituto da Segurança Social.

Jackson, S., \& Cameron, C. (Eds.). (2014). Improving access to further and higher education for young people in public care. European policy and practice. London: Jessica Kingsley Publishers.

Lausten, M., \& Fredriksen, S. (2016). Do you love me? An empirical analysis of the feeling of love amongst children in out-of-home care. Scottish Journal of Residential Child Care, 15(3), 90-103. 
Llosada-Gistau, J., Montserrat, C., \& Casas, F. (2014). The subjective well-being of adolescents in residential care compared to that of the general population. Children and Youth Services Review, 52, 150-157. https://doi.org/10.1016/j.childyouth.2014.11.007.

Llosada-Gistau, J., Casas, F., \& Montserrat, C. (2017). What matters in for the subjective well-being of children in care? Child Indicators Research, 10, 735-760. https://doi.org/10.1007/s12187-016-9405-z.

Martins, P. (2006). A qualidade dos serviços de protecção às crianças e jovens - as respostas institucionais. Revista Infância e Juventude, n. ${ }^{\circ} 3,103-114$.

Martins, C., Belsky, J., Marques, S., Baptista, J., Silva, J., Mesquita, A., et al. (2013). Diverse physical growth trajectories in institutionalized Portuguese children below age 3: relation to child, family, and institutional factors. Journal of Pediatric Psychology. https://doi.org/10.1093/jpepsy/jss129.

Melendro, M., Montserrat, C., Iglesias, A., \& Cruz, L. (2016). Effective social education of exclusion: Contributions from social pedagogy. European Journal of Social Work, 19, 931-945. https://doi. org/10.1080/13691457.2015.1082982.

Montserrat, C., Dinisman, T., Bălţătescu, S., Brînduşa, A., \& Casas, F. (2015). The effect of critical changes and gender on adolescents' subjective well-being: comparisons across 8 countries. Child Indicators Research, 8, 111-131. https://doi.org/10.1007/s12187-014-9288-9.

Montserrat, C., \& Casas, F. (2018). The education of children and adolescents in out-of-home care: a problem or an opportunity? Results of a longitudinal study. European Journal of Social Work, 21, 750-763. https://doi.org/10.1080/13691457.2017.1318832.

Oliveira, P., Fearon, R., Belsky, J., Fachada, I., \& Soares, I. (2014). Quality of institutional care and early childhood development. International Journal of Behavioral Development, 39, 1-10. https://doi. org/10.1177/0165025414552302.

Ortúzar, H., Miranda, R., Oriol, X., \& Montserrat, C. (2019). Self-control and subjective-wellbeing of adolescents in residential care: the moderator role of experienced happiness and daily-life activities with caregivers. Children and Youth Services Review, 98, 125-131. https://doi.org/10.1016/j. childyouth.2018.12.021.

Parfit, D. (1984). Reasons and persons. Oxford: Oxford University Press.

Pressman, S. D., \& Cohen, S. (2005). Does positive affect influence health? Psychological Bulletin, 131, 925971. https://doi.org/10.1037/0033-2909.131.6.925.

Rees, G., Goswami, H., Pople, L., Bradshaw, J., Keung, A., \& Main, G. (2013). The good childhood report 2013. Available from: https://www.childrenssociety.org.uk/sites/default/files/TheGoodChildhoodReport2013.pdf. Accessed 15 Jan 2019

Rodrigues, S., Barbosa-Ducharne, M., \& Del Valle, J. (2013). The quality of residential child Care in Portugal and the example of its development in Spain. Papeles del Psicólogo, 34(1), 11-22.

Rodrigues, S., \& Barbosa-Ducharne, M. (2017). Acolhimento Residencial em Portugal: Tempo de encontrar respostas sem deixar de questionar. In J. P. Gaspar \& E. Santos (Eds.), Acolhimento Juvenil no mundo - respostas sociais e estratégias terapêuticas fundadas na cultura (pp. 155-179). Lisboa: Edições ex-Libris.

Rutter, M. (1991). A fresh look at «maternal deprivation». In P. Bateson (Ed.), The development and integration of behaviour: Essays in honour of Robert Hinde (pp. 331-374). New York: Cambridge University Press.

Rutter, M. (1995). Clinical implications of attachment concepts: retrospect and prospect. Journal of Child Psychology and Psychiatry, 36(4), 549-571.

Salovey, P., Rothman, A. J., Detweiler, J. B., \& Steward, W. T. (2000). Emotional states and physical health. American Psychologist, 55, 110-121. https://doi.org/10.1037/0003-066X.55.1.110

Sastre, M., \& Ferrière, G. (2000). Family "decline" and the subjective well-being of adolescents. Social Indicators Research, 49, 69-82. https://doi.org/10.1023/A:100693512.

Schütz, F., Sarriera, J., Bedin, L., \& Montserrat, C. (2015). Subjective well-being of children in residential care: Comparison between children in institutional care and children living with their families. Psicoperspectivas, 14(1), 19-30.

The Children's Society (2013). The good childhood report http://www.childrenssociety.org. uk/sites/default/files/tcs/good_childhood_report_2013_final.pdf. Accessed 15 Jan 2019.

Valois, R. F., Zullig, K. J., Huebner, E. S., \& Drane, J. W. (2004). Life satisfaction and suicide among high school adolescents. In A. Dannerbeck, F. Casas, M. Sadurni, \& G. Coenders (Eds.), Quality-oflife research on children and adolescents (Social Indicators Research Series) (Vol. 23, pp. 81-105). Dordrecht: Springer. https://doi.org/10.1007/978-1-4020-2312-5_5. 